\title{
РОЛЬ ІНФОРМАЦЙНО-КОМУНІКАТИВНИХ ТЕХНОЛОГІЙ У НАВЧАЛЬНОМУ ПРОЦЕСІ
}

\author{
Yu. O. Danylevych, L. V. Naumova, L. S. Milevska-Vovchuk \\ I. Horbachevsky Ternopil National Medical University

\section{THE PART OF INFORMATION AND COMMUNICATION TECHNOLOGIES IN THE EDUCATIONAL PROCESS}

\begin{abstract}
Анотація. У статті розглянуто провідні стратегії організації навчання студентів в умовах дистанційного викладання на практичних кафедрах Тернопільського національного медичного університету.

Показано, що зростання творчої компоненти освіти та підвищення активності всіх учасників навчального процесу як студентів, так і викладачів сприяє модифікації інтерактивного навчання, пов’язаного з використанням комп'ютерних систем, мультимедійних технологій; навчально-методичної продукції нового покоління.

Розглянуто інноваційну навчальну технологію та сучасні методи викладання як загальнодидактичний процес, що полягає у використанні сукупності оригінальних способів і прийомів спільної діяльності суб'єктів освітнього процесу, спрямованих на досягнення мети навчання, розвитку особистості та креативно-фахового здобуття знань і компетенцій відповідно до завдань підготовки професіоналів нового часу.

Проаналізовано і доведено, що найкращого результату в навчанні можна досягнути тоді, коли ролі викладача й студента врівноважені: обидва працюють для того, щоб навчатися, ділитися своїми знаннями, досягненнями свого життєвого досвіду.

Впровадження інформаційно-комунікаційних технологій у навчальний процес, на практичних заняттях з терапії, сприяє більш повному оволодінню системою знань та вмінь, розвиває творчу спрямованість пізнавальної діяльності студентів, забезпечує об’єктивний самоконтроль і самоперевірку отриманих знань, допомагає формуванню відповідних професійних компетентностей та особистісних якостей, дозволяє викладачам забезпечити диференційований підхід у навчанні.

У роботі проаналізовано доступні інтерактивні методики та форми навчання, узагальнено найоптимальніші способи, форми і методи оцінювання роботи студентів на онлайн-платформах, доступних у даний час.

Автори стверджують, що педагогічні підходи до викладання постійно вимагають пошуку новітніх засобів, які здатні принести в навчальний процес елемент новизни, підвищити інтерес здобувачів вищої освіти, особливо в період карантину.
\end{abstract}

Ключові слова: інноваційні технології; тренінгові засоби; компетенції; інформаційно-комунікаційні технології.

Abstract. The article considers the leading strategies of the organization of students' education in the conditions of distance teaching at the practical departments of I. Horbachevsky Ternopil National Medical University.

It is shown that the growth of the creative component of education and increase of the activity of all participants in the educational process, both students and teachers, contributes to the modification of interactive learning associated with the use of computer systems, multimedia technologies; educational and methodical products of the new generation.

The authors consider innovative educational technology and modern teaching methods as a general didactic process, which consists in the use of a set of original methods and techniques of joint activities of the subjects of the educational process aimed at achieving the goal of learning, personal development and creative acquisition of knowledge and competencies according to professionals training tasks in modern times.

It is analyzed and proved that the best result in learning can be achieved when the roles of teacher and student are balanced: both work to learn, to share their knowledge, achievements of their life experience.

Introduction of information and communication technologies in the educational process, in classes of practical therapy, promotes a fuller mastery of the system of knowledge and skills, develops creative orientation of students' cognitive activity, provides objective self-control and self-examination of knowledge, helps to form relevant professional competencies and personal qualities and allows teachers to provide a differentiated approach in learning.

() Ю. О. Данилевич, Л. В. Наумова, Л. С. Мілевська-Вовчук 
The paper analyzes the available interactive methods and forms of learning, summarizes the best ways, forms and methods of evaluating the work of students on online platforms currently available.

The authors affirm that pedagogical approaches to teaching constantly require the search for new tools that can bring an element of novelty to the educational process, increase the interest of higher education pupils, especially during quarantine.

Key words: innovative technologies; training tools; competencies; information and communication technologies.

Вступ. Освіта має орієнтуватися на перспективи розвитку суспільства, а це означає, що в сучасній освіті необхідно застосовувати найновітніші інформаційні технології. Створення добротного інформаційного середовища $є$ ключовим завданням на шляху переходу до інформаційного суспільства. Масове впровадження інформаційно-комунікативних технологій (IKT) в освітню сферу висуває проблему комп’ютеризації закладів освіти в розряд пріоритетних. Розвиток і впровадження IKT спрямовані на їх комплексне інформаційноресурсне й методичне забезпечення [2]. Однією 3 ключових умов успішності для фахівця у будьякій галузі у XXI столітті є безперервне навчання впродовж життя. Однак особливо важливим безперервний професійний розвиток є для освітян, які, за сутністю своєї професії, повинні бути на вістрі змін, а інколи і випереджати інноваційні процеси, аби дати змогу молодому поколінню адаптуватися в нових умовах професійного ринку. Поняття «освітньо-навчальні інновації» та «інформаційно-комунікативні технології» використовуються у різних педагогічних процесах для визначення адекватних механізмів впливу, скоординованих у єдину програму, яка охоплює всі напрями освітніх трансформацій вищих навчальних закладів і направлена на інтерактивну дію. Так, категоріальне наповнення інновації в освітньому процесі можна спроектувати на дуальний контекст, зокрема розглядати як процес, що полягає у масштабній або частковій зміні системи і відповідної діяльності, та готовий продукт, тобто очікувані результати цієї праці. У діяльнісному аспекті інноваційними слід вважати оригінальні, новаторські способи та прийоми педагогічних дій і засобів. Отже, інноваційне навчання - це постійне прагнення до переоцінки цінностей, збереження тих із них, які мають незаперечне значення, і відкидання тих, що вже застаріли. Інновації у навчальній діяльності пов’язані з активним процесом створення, поширення нових методів і засобів (нововведень) для вирішення дидактичних завдань підготовки фахівців у гармонійному поєднанні класичних традиційних методик та результатів творчого пошуку, застосування нестандартних, прогресивних технологій, оригінальних дидактичних ідей і форм забезпечення освітнього процесу [3, 4].

Передусім, це має полягати в сучасному моделюванні, організації нестандартних лекцій, практичних, семінарських занять; індивідуалізації засобів навчання; кабінетного, групового і додаткового навчання; факультативного, за вибором студентів, поглиблення знань; проблемно-орієнтованого навчання; науково-експериментального при вивченні нового матеріалу; розробці нової системи контролю оцінки знань; застосуванні комп’ютерних, мультимедійних технологій; навчально-методичної продукції нового покоління. Таким чином, серед сучасних технологій навчання, своєчасність і корисність яких підтверджена досвідом роботи ВНЗ, слід виділити: особистісно-орієнтовані, інтеграційні, колективної дії, інформаційні, дистанційні, творчо-креативні, модульно-розвивальні тощо. Вони мають стати основою для ефективної дидактикометодичної, психологічної, комунікативної взаємодії студента і викладача та прояву компетентних навичок. У цій технології особистість, тобто здобувач вищої освіти, - головний суб'єкт, мета, а не засіб досягнення поставленої мети.

Мета статті - покращити якість викладання в умовах дистанційного навчання на практичних кафедрах Тернопільського національного медичного університету.

Теоретична частина. Головною відмінною рисою навчання з використанням інформаційнокомунікаційних технологій є безпосереднє застосування комп’ютера як засобу навчання, використання якого кардинально змінює систему форм і методів викладання навчальних дисциплін. При цьому використання IKT у навчальному процесі виступає не самоціллю, а педагогічно виправданим підходом, який дозволить отримати суттєві переваги у порівнянні з традиційними технологіями організації навчального процесу.

На думку багатьох вчених, впровадження комп'ютерних засобів у навчальний процес розширило теорію і методику освіти шляхом застосування нових дидактичних засобів $[2,5]$. Основними напрямками застосування IKT у навчальному процесі є: 
- розробка методичних і дидактичних матеріалів (презентації, зображення, анімація тощо);

- управління навчальним процесом вищої і середньої школи;

- цілеспрямований пошук навчальної інформації у мережі «Інтернет»;

- проведення експерименту за допомогою комп’ютерних моделей, математична обробка результатів експерименту;

- організація інтелектуального дозвілля студентів;

- розробка web-ресурсів навчального призначення (дистанційне навчання, масові онлайн-курси);

- розробка та впровадження педагогічних програмних засобів [6, 7].

Власний досвід і педагогічна практика показали, що застосування інформаційно-комунікаційних технологій дозволяє значно підвищити ефективність навчального процесу під час самостійної роботи студентів, на лекціях, лабораторних, практичних і семінарських заняттях. Впровадження інформаційно-комунікаційних технологій у навчальний процес сприяє більш повному оволодінню системою знань та вмінь, розвиває творчу спрямованість пізнавальної діяльності студентів, забезпечує об’єктивний самоконтроль і самоперевірку отриманих знань, допомагає формуванню відповідних професійних компетентностей та особистісних якостей, дозволяє забезпечити диференційований підхід [4, 8].

Стрімке розширення за останні десятиліття інформаційно-комунікаційних технологій, вплив величезного потоку інформації на людину спричинили потребу системи освіти реагувати на виклики часу, а тому виникла потреба у використанні сучасних технологій навчання, які вдало вписуються в систему традиційної освіти. До таких можна віднести: електронне навчання, мобільне навчання, всепроникаюче навчання, «перевернуте навчання», що становлять форми активного навчання.

Зупинимось на визначеннях кожного з них.

Електронне навчання (e-learning) - система навчання за допомогою інформаційних, електронних технологій. Часто тлумачення як синонім таких понять: дистанційне навчання, навчання із застосуванням комп’ютерів, мережеве навчання, віртуальне навчання, мультимедійне навчання. E-learning - навчання за допомогою Інтернету i мультимедіа. Мобільне навчання (m-learning) - це передача навчальної інформації на мобільні пристрої з використанням WAP i GPRS технологій. Всепроникаюче навчання (u-learning) - технології неперервного навчання з використанням інформаційно-комунікаційних засобів у всіх сферах життя суспільства.

Перевернуте навчання (flipped-learning) - це форма активного навчання, що дозволяє «перевернути» звичайний процес навчання таким чином: студенти поза аудиторією переглядають відповідні навчальні матеріали, що будуть розглядатися на наступному занятті, самостійно вивчають теоретичний матеріал, а в аудиторії здійснюють його обговорення, виконуючи практичні завдання.

Змішане навчання (blended-learning) - це об’єднання формальних засобів навчання - роботи в аудиторіях, вивчення теоретичного матеріалу 3 неформальними, наприклад, обговоренням за допомогою електронної пошти й Інтернет-конференцій. Змішана форма навчання органічно поєднує в собі як денні, так і дистанційні форми навчання. Це модель, яка поєднує традиційну і електронну моделі навчання. Нині найбільшого використання в навчальному процесі отримала змішана модель навчання [1, 5, 7].

Одна з ознак навчального процесу - його керованість, що передбачає можливість планування i проектування навчального процесу, використання різних засобів і методів для корекції результатів навчання. У керованої навчальної системи ланцюжок педагогічних дій вибудовується чітко відповідно до поставленої мети навчання. Одна з ознак керованості процесу навчання полягає в тому, що: навчальний матеріал розбивається на смислові блоки; він має структуру; процес навчання має систематичний плановий характер. Так, при навчанні на практичних кафедрах терапії план складено таким чином, що кожного дня студенти мають чітко структуровану тему. Кілька тем об’єднуються за змістом у модуль. Після завершення кожної теми підбивається підсумок. Діагностичні процедури є невід'ємною частиною технології, присутні на всіх ï̈ етапах і містять показники та інструментарій вимірювання результатів діяльності [6].

Сьогодні доволі розповсюдженими є інтегровані заняття із застосуванням мультимедійних засобів, а навчальні презентації часто стають невід'ємною частиною викладу нового матеріалу. Використання відеосюжетів й анімаційних ефектів дозволяє перейти від традиційної технології подання матеріалу з використанням дошки та крейди до використання нового освітнього середовища, що містить всі можливості подання навчальної інформації в електронному вигляді. За рахунок цього мультимедіа-лекції 
можна використовувати для викладання практично всіх курсів, проте особливу зацікавленість викликає у студентів практичних кафедр при демонстрації клінічних випадків, рідкісних захворювань чи особливостей діагностики низки патологій. Викладач за допомогою мультимедіа в аудиторії отримує потужний інструментарій для представлення навчальної інформації в різній формі (текст, графіка, анімація, звук, відео), самостійно визначає послідовність та форми викладу матеріалу. У разі потреби можна демонструвати відеофільми, записані викладачами кафедри для представлення додаткових пояснень складних питань діагностики чи лікування, якщо це необхідно для конкретної аудиторії. Для проведення семінарських і практичних занять інформаційно-комунікаційні технології теж мають величезні потенційні можливості підвищення ефективності навчання. Ефективними $є$ Internetметоди, які дозволяють отримати значні переваги під час організації навчальної діяльності студентів, а саме: забезпечення можливості самостійного пошуку потрібної інформації серед величезної кількості електронних джерел; використання хмарних технологій для збереження навчальної інформації; забезпечення комунікації між студентами та викладачем; використання різних форм контролю навчальних досягнень студентів [1, 8].

Проведення олімпіад, вебінарів та інших форм навчальної та наукової діяльності в онлайн-режимі особливої актуальності набули під час локдауну, спричиненого COVID-інфекцією. Саме завдяки новітнім комунікативним технологіям студенти отримали змогу дискутувати незалежно від місця їхньої локації, презентувати свої знання і наукові наробки та отримувати сучасну інформацію «з перших уст».

Слід зазначити, що інформаційно-комунікаційні технології доречно використовувати у поєднанні різних форм навчання задля отримання максимального навчального ефекту. Так, презентації, пошук інформації в Інтернеті, текстовий процесор часто використовуються у проектній діяльності, під час якої студенти разом виконують навчальний проект у вигляді певного практичного завдання. Проте не слід забувати про вагому роль викладача-наставника, який допоможе розібратися з потоком інформації, відокремить фейкові дані від правдивих і навчить не загубитися на просторах Інтернету. Ще однією новинкою в дистанційному навчанні є створення та використання електронних підручників, які повинні бути не лише «нафаршированою» програмою, а й містити дидактичний до- свід викладача, актуальне та наукове інформаційне наповнення з певної навчальної дисципліни. Слід зазначити, що викладання дисципліни з використанням інформаційно-комунікаційних технологій передбачає готовність викладача до такої форми навчального процесу, наявність у нього достатньої інформаційної культури. Він повинен володіти не тільки предметною областю, а й бути обізнаним в існуючих технологіях навчання з використанням IKT, способах досягнення певної дидактичної мети за допомогою інформаційних технологій. Крім цього, викладач повинен мати хоча б поверхневе уявлення про наявне апаратне і програмне забезпечення, яке може бути використане для вивчення відповідної дисципліни. Не слід забувати, що об’єктом педагогічної діяльності професорськовикладацького складу вищих навчальних закладів $є$ молодь, юнаки та дівчата з певними задатками, потребами, інтересами, особливостями пізнавальних та емоційно-вольових процесів. У зв'язку 3 цим перед викладачами вищої школи постає надзвичайно відповідальне завдання - допомогти їм стати висококваліфікованими фахівцями, здатними знайти місце на ринку праці, творчо реалізувати набуті у вищому навчальному закладі знання та практичні уміння. Характеризуючи особливості педагогічної діяльності, В. О. Сухомлинський підкреслював: «Наша праця - формування людини, i це накладає на нас особливу, ні з чим не зрівняну відповідальність» [1, 7]. Основними напрямами діяльності викладача вищого навчального закладу є: навчальна, науково-методична, науково-дослідна, виховна та дорадча. Так, навчальна діяльність спрямована на організацію та здійснення процесу навчання відповідно до нормативних документів: проведення лекційних, семінарсько-практичних занять, консультацій, контрольних заходів, керівництво курсовими і дипломними роботами тощо. Науково-методична діяльність пов'язана 3 підготовкою навчального процесу, його забезпеченням i удосконаленням. Виховна діяльність полягає в організації виховного впливу на майбутніх фахівців у процесі викладання навчальних дисциплін і в позааудиторній роботі. Науково-дослідна діяльність має за мету організацію наукових досліджень у певній галузі знань, підвищення наукового рівня та розвитку творчого потенціалу викладача і студента. Відомий російський педагог і письменник Л. Толстой підкреслював: «Хочеш наукою виховати учня, люби свою науку і знай їі, і учні полюблять i тебе, i науку, і ти виховаєш їх, але якщо сам не 
любиш їі, то скільки б ти не змушував учити, наука не справить виховного впливу». Дорадча діяльність має на меті надання професійної допомоги виробничникам, проведення наукових консультацій щодо підвищення якості виробничих процесів. Це також діяльність професорсько-викладацького персоналу в галузі підвищення професійної кваліфікації спеціалістів-практиків.

В освітній практиці, з метою зацікавлення студентів до співпраці, використовуємо такі педагогічні технології:

- професійно-ділові ігрові технології: дидактичні системи використання різноманітних «ігор», під час проведення яких формуються вміння вирішувати завдання на основі компромісного вибору (ділові та рольові ігри, імітаційні вправи, індивідуальний тренінг, комп’ютерні програми тощо) [6, 8]. Вагому роль у проведенні симуляцій відіграють медичні сайти, зокрема Medscape, Healio тощо, де можна знайти не лише клінічні випадки з детальним розбором пацієнтів з кожної терапевтичної дисципліни, а й у разі успішного вирішення тестових завдань отримати сертифікат;

- тренінгові засоби: система діяльності для відпрацювання певних алгоритмів вирішення типових практичних завдань за допомогою комп’ютера (психологічні тренінги інтелектуального розвитку, спілкування, розв’язання управлінських завдань, відпрацювання практичних навичок на симуляторах різної складності);

- інформаційно-комп’ютерні технології, що реалізуються в дидактичних системах комп’ютерного навчання на основі діалогу «людина - машина» за допомогою різноманітних навчальних програм (тренінгових, контролюючих, інформаційних тощо);

- діалогово-комунікаційні технології: сукупність форм і методів навчання, заснованих на діалоговому мисленні у взаємодіючих дидактичних системах суб’єкт-суб'єктного рівня. В освітній практиці диверсифікація навчальних технологій дозволяє активно і результативно їх поєднувати через модернізацію традиційного навчання та переорієнтацію його на ефективне, цілеспрямоване.

За такого підходу акцентується на особистісному розвитку майбутніх фахівців, здатності оволодівати новим досвідом творчого і критичного мислення, рольового та імітаційного моделювання пошуку вирішення навчальних завдань.

У цьому контексті інноваційну навчальну технологію та сучасні методи викладання слід розгляда- ти як загальнодидактичний процес, що полягає у використанні сукупності оригінальних способів і прийомів спільної діяльності суб’ єктів освітнього процесу, спрямованих на досягнення мети навчання, розвитку особистості та креативно-фахового здобуття знань і компетенцій відповідно до завдань підготовки професіоналів нового часу $[1,7]$.

На сьогоднішньому ринку освітніх послуг такими є інноваційні активні та інтерактивні методики навчання. Оскільки суттєво зростає творча компонента освіти, активізується роль усіх учасників навчального процесу, зміцнюється творчо-пошукова самостійність студентів, особливої актуальності набули концепції проблемного та інтерактивного навчання, пов'язаного з використанням комп’ютерних систем. Під час такого освітнього процесу студент може комунікувати з викладачем он-лайн, вирішувати творчі, проблемні завдання, моделювати ситуації, включаючи аналітичне і критичне мислення, знання, пошукові здібності.

Очікуваний результат: покращити якість викладання, сформувати індивідуальний підхід до ведення заняття, враховуючи специфіку дистанційного навчання із залученням новітніх технологій.

Висновки та перспективи подальших досліджень. Таким чином, структура й сутність інноваційного освітнього процесу відповідають характеру і швидкості соціальних змін у суспільстві, високим європейським стандартам підготовки конкурентоспроможних фахівців інноваційного типу. Проте жодна освітня технологія не може розглядатися як універсальна. Організація навчального процесу в сучасних умовах вимагає поєднання різних технологій, творчого підходу до використання кожної $з$ них, а також створення нових навчальних технологій.

Оскільки сучасний зміст освіти має орієнтуватися на використання інформаційних технологій, поширення інтерактивного, електронного навчання з доступом до цифрових ресурсів та інтелект-навчання для майбутнього є вкрай важливим. Розробка, впровадження і використання нових програм, зокрема 3 основ інтернет-безпеки, соціальних комунікацій у професійній підготовці медиків, впровадження навчальних матеріалів та продуктів нового покоління відповідно до вимог сучасної економіки та соціального запиту ринку праці дозволять майбутнім лікарям бути більш підготовленими до умов сьогодення і бути конкурентоспроможними на ринку праці. 


\section{Список літератури}

1. Воробйова О. Система забезпечення якості освіти: український досвід / О. Воробйова // Актуальні питання гуманітарних наук. - 2020. - Вип. 29, т. 1. - С. 259-264.

2. Крицький I. О. Запровадження кредитно-модульної системи у практику роботи факультету ТДМУ / I. О. Крицький, П. В. Гощинський, Г. А. Крицька // Медична освіта. - 2012. - № 4. - С. 18-19.

3. Мороз Л. В. Сучасні методичні підходи до навчання й оцінювання знань студентів на кафедрі інфекційних хвороб з курсом епідеміології / Л. В. Мороз, Д. В. Палій // Сучасні методологічні технології керування навчальним процесом у вищих медичних навчальних закладах : тези доповідей навч.-метод. конф. - Вінниця, 2018. С. $117-118$.

4. Мунтян О. В. Кейс-метод - сучасна форма інтерактивного навчання студентів / О. В. Мунтян, В. Л. Мунтян // Сучасні методологічні технології керування навчальним процесом у вищих медичних навчальних закладах : тези доповідей навч.-метод. конф. - Вінниця, 2018. - С. 120-121.

5. Островський I. М. Рольова гра як засіб навчання та контролю знань субординаторів / I. М. Островський,

\section{References}

1. Vorobiova, O. (2020). Systema zabezpechennia yakosti osvity: ukrainskyi dosvid [Education quality assurance system: Ukrainian experience]. Aktualni pytannia humanitarnykh nauk - Current Issues of the Humanities, 29, 259-264 [in Ukrainian].

2. Krytskyy, I.O., Hoschynskyy, P.V., \& Krytska, H.A. (2012). Zaprovadzhennia kredytno-modulnoi systemy u praktyku roboty fakultetu TDMU (2012) [Introduction of the credit-transfer system into the practice of the faculty of TDMU]. Medychna osvita - Medical Education, 4, 18-19 [in Ukrainian].

3. Moroz, L.V., \& Paliy, D.V. (2018). Suchasni metodychni pidkhody do navchannia i otsiniuvannia znan studentiv na kafedri infektsiinykh khvorob z kursom epidemiolohii [Modern methodical approaches to teaching and assessing students' knowledge at the Department of Infectious Diseases with a Course in Epidemiology]. Abstracts of the Educational-Methodical Conference "Modern Methodological Technologies of Educational Process Ma nagement in Higher Medical Institutions”. Vinnytsia [in Ukrainian].

4. Muntyan, O.V., \& Muntyan, V.L. (2018). Keysmetod - suchasna forma interaktyvnoho navchannia stude ntiv [The case method is a modern form of online student learning]. Suchasni metodolohichni tekhnolohii keruvannia navchalnym protsesom u vyshchykh medychnykh navchalnykh zakladakh: tezy dopovidei navch.-metod. konf. [Abstracts of the Educational-Methodical Conference "Modern Methodological Technologies of Educational Process Management in Higher Medical Institutions"]. Vinnytsia [in Ukrainian].
Є. В. Прохоров // Медична освіта. - 2004. - № 1. C. $49-51$.

6. Підготовка сімейних лікарів на сучасному етапі: вирішені та невирішені проблеми / Г. І. Лисенко, О. Б. Яценко, Л. В. Хіміон [та ін.] // Сімейна медицина. - 2011. - № 3. - С. 5-6.

7. Применение компьютерных и мультимедийных технологий для преподавания травматологии и ортопедии / В. А. Бабоша, В. А. Начевкин, Г. В. Лобанов [и др.] // Досвід та проблеми підготовки медичних кадрів : зб. наук. праць. - Донецьк, 2005. - С. 74-76.

8. Харитонюк Р. О. Тенденції захворюваності дітей Рівненської області на інфекційну патологію / Р. О. Харитонюк // Современная педиатрия. - 2013. № 4 (52). - С. 45-46.

9. Шаров С. В. Електронні засоби навчального призначення: характеристика та вимоги / С. В. Шаров, T. I. Мартинюк // Проблеми та перспективи формування національної гуманітарно-технічної еліти. - 2012. № 32-33. - С. 236-241.

5. Ostrovskyi, I.M., \& Prohorov, Ye.V. (2004). Rolova hra yak zasib navchannia s kontroliu znan subordynatoriv [Role play a means of teaching and controlling the knowledge of subordinates]. Medychna osvita - Medical Education, 1, 49-51 [in Ukrainian].

6. Lysenko, H.I., Yatsenko, O.B., \& Himion, L.B. (2011). Pidhotovka simeinykh likariv na suchasnomu etapi: vyrisheni ta nevyrisheni problemy [Training of family physicians at the current stage: resolved and unresolved problems]. Simeina medytsyna - Family Medicine, 3, 5-6 [in Ukrainian].

7. Babosha, V.A., Nachevkin, V.A., \& Lobanov, G.V. (2005). Primeneniye kompyuternykh i multimediynykh tekhnologiy dlya prepodavaniya travmatologii i ortopedii [The use of computer and multi-media technologies for the teaching of traumatology and orthopedics]. Dosvid ta problemy pidhotovky medychnykh kadriv: zb. nauk. prats Experience and problems of medical training. Donetsk [in Russian].

8. Harytoniuk, R.O. (2013). Tendentsii zabolevayemosti detey rovenskoy oblasti infektsionnoy patologiyey [Trends in the incidence of children of the Rivne region with infectious pathology]. Sovremennaya pediatriya - Modern Pediatrics, 4 (52), 45-46 [in Russian].

9. Sharov, S.V., Martyniuk, T.I. (2012). Electronni zasoby navchalnoho pryznachennia: characterustuki ta vymohy [Electronic teaching aids: characteristics and requirements]. Problemy ta perspektyvy formuvannia natsionalnoi humanitarno-tekhnichnoi elity - Problems and Prospects of Formation of the National Humanitarian and Technical Elite, 32-33, 236-241 [in Ukrainian]. 